SVU- International Journal of Veterinary Sciences, 4(1): 66-78, 2021.

Print ISSN: 2535-1826

Research Article

Open Access

\title{
A descriptive morphometric approach to the skull in Red fox (Vulpes vulpes) of Egypt
}

\section{Ramy K. A. Sayed ${ }^{1, *}$, Hazem S. Hamoda ${ }^{2}$}

${ }^{1}$ Department of Anatomy and Embryology, Faculty of Veterinary Medicine, Sohag University, 82524 Sohag, Egypt. ${ }^{2}$ Department of Anatomy and Embryology, Faculty of Veterinary Medicine, Aswan University, 81528 Aswan, Egypt.

\section{Abstract}

Craniofacial anatomy is essential to understand the locative relationships of organs in specific region of each species. This study was aimed to investigate morphometric parameters of the skull of the Red fox of Egypt. Thirteen skulls of about 2.5-4 years-old male Red fox were carefully processed using standard method. Altogether, 29 different osteometric measurements including 7 different indices were estimated. The average total length and width of the skull in the Red fox were $17.64 \pm 2.68 \mathrm{~cm}$ and $8.73 \pm 1.76 \mathrm{~cm}$, respectively, with cephalic index of $49.27 \pm 3.42$. The cranial length of the Red fox's skull was about two-fold of its width, with cranial capacity of $49.54 \pm 3.75$ cc, as well as cranial and basal indices were $49.87 \pm 3.96$ and $30.97 \pm 2.33$, respectively. The foramen magnum width was higher than its height, with foramen magnum index of 71.52 \pm 3.86 . The cranial length of the Red fox's skull was higher than the facial length, with facial index of $62.70 \pm 4.01$. The orbital length was higher than the orbital width, and the interorbital distance was wider caudally and narrower in the middle, with orbital capacity and orbital index of $9.34 \pm 0.17 \mathrm{cc}$ and $97.87 \pm 5.22$, respectively. In conclusion, measured osteometric parameters of the Red fox's skull will provide baseline anatomy information on the skull morphometry, which is necessary for comparative anatomy and clinical veterinary practice. The findings reported here will assist other clinical studies conducting on the Red fox's head.

Keywords: Anatomy, Craniofacial, Orbit, Red fox, Skull.

DOI: 10.21608/svu.2021.55887.1093 Received: December30, 2020 Accepted: March 22, 2021 Published: March 24, 2021 Corresponding Author: Ramy K. A. Sayed: E-mail: ramy.kamal@vet.sohag.edu.eg.

Citation: Sayed and Hamoda, 2021. A descriptive morphometric approach to the skull in Red fox (Vulpes vulpes) of Egypt. SVU-IJVS 2021, 4(1): 66-78.

Copyright: () Sayed and Hamoda. This is an open access article distributed under the terms of the creative common attribution license, which permits unrestricted use, distribution and reproduction in any medium provided the original author and source are created.

Competing interest: The authors have declared that no competing interest exists. 


\section{INTRODUCTION}

The Red fox (Vulpes vulpes) is the most widely-distributed carnivore across the world. It belongs to order Carnivora, family Canidae (Statham et al., 2014), and is considered the largest true fox found in North Africa, where its distribution is more detectable in regions close to human habitats and agricultural area (Osborn and Helmy, 1980). In Egypt, Red fox is found along the coast, Nile Delta as well as Nile Valley, up to Sudanese borders (Stuart and Stuart, 2017), and is proposed as one of the most adaptable mammals in Egypt, which can survive in a wide range of habitats (Saleh, 1993). This outstanding adaptability of Red fox is due to its capability to feed on a diversified dietary composition in various environmental conditions (Basuony et al., 2005). Generally, foxes are omnivores depending on their feeding on eating small mammals, reptiles, birds, fishes, insects and the variety of fruits (Fedriani et al., 2000).

Red foxes play a crucial role in biology conservation (Virgós and Travaini, 2005), and also have a special position in the field of zoonotic Medicine. World Health Organization reports have been mentioned that Red foxes are reservoirs for rabies that is a public health issue in the Middle East countries, including Egypt (Knobel et al., 2005; Seimenis, 2008). Furthermore, Red foxes have been suggested as a probable reservoir of canine distemper virus (Aničić et al., 2018). Beside their zoonotic importance, Red foxes hold economic importance in traditional fur countries (Stubbe, 1980).

Skull consists of bones forming cavities for location of brain; organs of vision, smell, hearing and equilibrium, in addition to initial parts of the digestive and respiratory tracts. The bones of the skull articulate with each other by visible and well-differentiated sutures. Skull is divided into two well-defined part; cranium and face (Constantinescu and Schaller, 2012; König and Liebich, 2013). Although, morphological and morphometrical studies on the skull reflect contributions of environmental and genetic components to individual development and depict ecophenotypic and genetic variations, which are foundations of clinical practices (Wehausen and Ramey, 2000). Moreover, craniofacial anatomy is pivotal for understanding the locative relationships of organs in specific region, and skull typology is an essential aspect of the craniofacial anatomy of the species (Olopade and Onwuka, 2008). Furthermore, studying morphometric measurements of the skull plays an important role in understanding skull morphology of various animal species, determining skull deformations with detecting their causes (Onar and Güneş, 2003), and differentiating animal skulls of certain regions (Mazák, 2008).

Cranial dimensions and fusion of cranial sutures were previously reported among indicators used for determination of age in Red fox (Cavallini and Santini, 1995). Moreover, the occipital bone has a significant role in determination of the sex in forensics or anthropology (Rogers, 2005). Recently, a method based on using various skull parameters for accurate determining of the age has been reported (Guskov, 2014). Although wide range of osteometric analyses had been performed on mammalian skull, there is a scanty literature available on gross morphometric details of skull in Red fox. Thus, this study was planned to provide a detailed comprehensive morphometric description of the Red fox's skull, which will be of great significance for taxonomic 
affiliations, and could be used for clinical application of veterinarians.

\section{MATERIALS AND METHODS}

\section{Samples}

This study was performed and approved in accordance with the Ethics Committee of Faculty of Veterinary Medicine, Sohag University, Egypt. Thirty heads of adult male Red fox were brought to the Department of Anatomy and Embryology, Faculty of Veterinary Medicine, Sohag University, Egypt. The age of the animals was 2.5-3.5 years. The skull was carefully processed for skeleton preparation by using the boiling maceration technique as described previously (Simoens et al., 1994).

\section{Measurements used}

A total of 29 parameters were measured and analyzed for morphometry in this study including facial, cranial, orbital, nasal and palatine parameters (Fig. 1), as well as craniofacial indices. Furthermore, capacities of cranial and orbital cavities were measured using mustard seeds (Saber and Gummow, 2015; Dalga et al., 2018; Özkan et al., 2019; Gündemir et al., 2020). For measuring the capacity of the orbital capacity, all foramina open in the orbital cavity and also the communication between the orbit and temporal fossa were blocked with cotton, followed by filling of the cavity with mustard seeds till the level of the orbit rim (Sarma, 2006; Saber and Gummow, 2015). Similarly, all foramina open in the cranium were closed with cotton for measuring the capacity of its cavity, and then the cavity was filed with mustard seeds though the foramen magnum until its rim. The contents of the cavities were emptied in a measuring cylinder for estimating their capacities. Osteometric parameters measured in this study were as following:

\section{Skull parameters:}

1. Total skull length: The distance from the midpoint of the dorsal margin of the foramen magnum to the level of the middle point on the rostral margin of the incisive bone.

2. Basal length: The distance between the incisive bones to the intercondylar fossa.

3. Short skull length: The distance from the level of $2^{\text {nd }}$ premolar to the level of intercondylar fossa.

4. Skull width: The distance between the two zygomatic arches.

5. Skull index: Skull width / total skull length X 100 (Saber and Gummow, 2015; Gündemir et al., 2020).

\section{Cranial parameters:}

6. Cranial length: The distance from the middle point of nuchal crest to the junction of the left and right nasofrontal sutures.

7. Cranial width: The maximum distance between highest points of the parietal bones.

8. Cranial index: Cranial width / cranial length X 100 (Saber and Gummow, 2015; Gündemir et al., 2020).

9. Basal index: Cranial width / basal length X 100 (Özcan et al., 2010; Gündemir et al., 2020).

10. Cranial capacity.

\section{Foramen magnum parameters:}

11. Foramen magnum height: The distance between middle points of dorsal and ventral margins of the foramen magnum.

12. Foramen magnum width: The distance between two occipital condyles.

13. Foramen magnum index: Foramen magnum height / foramen magnum width X 100 (Özcan et al., 2010; Gündemir et al., 2020).

\section{Facial parameters:}


14. Facial length: The distance from the fronto-nasal suture to the midline of the incisive bone.

15. Facial width: The distance between caudal extents of the orbital rims.

16. Least facial width: The distance between cranial margins of the orbits.

17. The distance from the infraorbital foramen to the cranial margins of the orbits.

18. The distance from the infraorbital foramen to the alveolar process of maxilla.

19. Facial index: Facial width / facial length X 100 (Saber and Gummow, 2015; Gündemir et al., 2020).

\section{Orbital parameters:}

20. Orbital length: The vertical distance between supraorbital and infraorbital rims of the orbit.

21. Orbital width: The horizontal distance between rostral and caudal margins of the orbital cavity.

22. Orbital index: Orbital width / orbital length X 100 (Saber and Gummow, 2015; Gündemir et al., 2020).

23. Inter-orbital distance:

i. At rostral level: The distance between the junction of frontolacrimal sutures of both sides at the rostral limit of the orbit.

ii. At middle level: The distance between supraorbital borders of orbital cavity of both sides.

iii.At caudal level: The distance between the junctions of the zygomatic bone at the caudal margin of the orbit of both sides.

24. Orbital capacity

\section{Nasal parameters:}

25. Greatest nasal bone length.

26. Greatest nasal bones width.

27. Nasal index: Greatest nasal bones width / greatest nasal bone length $\mathrm{X}$
100 (Özcan et al., 2010; Gündemir et al., 2020).

\section{Palatine parameters:}

28. Palatine length: The distance from the rostral midline of incisive bone to the caudal margin of the palatine bone.

29. Palatine width: The distance across the outer border of the molars.
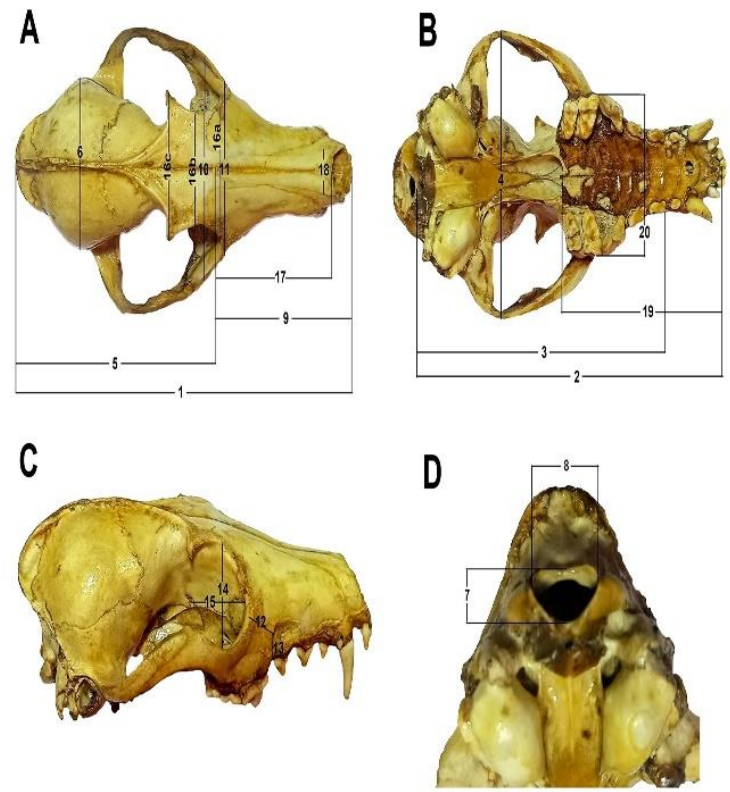

Fig. 1. Measurement of the skull of Red fox. (A) Dorsal view, (B) ventral view, (C) lateral view, (D) caudal view. 1, Total skull length; 2, basal length; 3 , short skull length; 4, skull width; 5, cranial length; 6 , cranial width; 7 , foramen magnum height; 8 , foramen magnum width; 9 , facial length; 10 , facial width; 11 , least facial width; 12 , the distance from the infraorbital foramen to the alveolar process of maxilla; 13 , the distance from the infraorbital foramen to the cranial margins of the orbits; 14 , orbital length; 15 , orbital width; 16a, inter-orbital distance at rostral level; 16b, interorbital distance at middle level; 16c, inter-orbital distance at caudal level; 17, greatest nasal bone length; 18, greatest nasal bones width; 19, palatine length; 20 , palatine width.

\section{Data Analysis}

The morphometric parameters were measured using a percussion digital vernier 
caliper. Photographs were taken by an OPPO phone camera. Nomina Anatomica Veterinaria (2017) was used for nominating various anatomical terms used in this study. The measured results were presented as mean $\pm \mathrm{SD}$, with minimum and maximum values.

\section{RESULT}

Analysis of the skull, cranial and foramen magnum parameters are shown in Table 1. The average total length of skull in the Red fox was $17.64 \pm 2.68 \mathrm{~cm}$, while the skull basal and short lengths were $15.21 \pm 1.76$ $\mathrm{cm}$ and $12.40 \pm 1.74 \mathrm{~cm}$, respectively. The skull width in the Red fox was $8.73 \pm 1.76$ $\mathrm{cm}$.

Table 1: Skull, cranial and foramen magnum measurements of the Red fox's skull

\begin{tabular}{|ccccc|}
\hline Parameters & Mean & SD & Min & Max \\
\hline Total skull length (cm) & 17.64 & 2.68 & 15.19 & 20.52 \\
\hline Basal length (cm) & 15.21 & 1.76 & 13.49 & 17.11 \\
\hline Short skull length (cm) & 12.40 & 1.74 & 10.54 & 14.20 \\
\hline Skull width (cm) & 8.73 & 1.76 & 6.89 & 10.41 \\
\hline Cranial length (cm) & 9.44 & 1.10 & 8.31 & 10.50 \\
\hline Cranial width (cm) & 4.68 & 0.21 & 4.51 & 4.90 \\
\hline $\begin{array}{c}\text { Cranial capacity (cc) } \\
\text { Foramen magnum } \\
\text { height (cm) }\end{array}$ & 49.54 & 3.75 & 45.21 & 51.79 \\
$\begin{array}{c}\text { Foramen magnum } \\
\text { width (cm) }\end{array}$ & 1.09 & 0.12 & 0.97 & 1.20 \\
\hline
\end{tabular}

Morphometric analysis of the cranium revealed that the mean cranial length of the Red fox's skull was $9.44 \pm 1.10 \mathrm{~cm}$ and the width was $4.68 \pm 0.21 \mathrm{~cm}$. The mean height of the foramen magnum of the Red fox's skull was $1.09 \pm 0.12 \mathrm{~cm}$, while its width was $1.52 \pm 0.10 \mathrm{~cm}$. The mean value of the cranial capacity in the Red fox's skull was $49.54 \pm 3.75$ cc. Measured cranial capacities of various animal species are summarized in Table 2.
The mean value of the facial length in the Red fox's skull was $7.84 \pm 1.19 \mathrm{~cm}$, while the facial width and least facial width were $4.89 \pm 0.44 \mathrm{~cm}$ and $3.85 \pm 0.37$ $\mathrm{cm}$, respectively (Table 3). Morphometric analysis of the skull of the Red fox showed that the distance between the level of the infraorbital foramen and the level of the cranial margins of the orbit was $1.60 \pm$ $0.35 \mathrm{~cm}$, and the distance from the level of the infraorbital foramen to the alveolar process of the maxilla was $0.90 \pm 0.22 \mathrm{~cm}$ (Table 3).

Table 2: Measured cranial capacities of various animal species

\begin{tabular}{|c|c|c|}
\hline Animal & $\begin{array}{l}\text { Cramial } \\
\text { capacity } \\
\text { (ce) }\end{array}$ & Reference \\
\hline $\mathbf{O x}$ & $440 \pm 39.50$ & Rao, 1967 \\
\hline Buffalo & $\begin{array}{c}627.45 \pm \\
62.12\end{array}$ & Rao, 1967 \\
\hline Camel & $\begin{array}{c}587.14 \pm \\
14.89\end{array}$ & $\begin{array}{c}\text { Sandhu and } \\
\text { Dhingra, } 1986\end{array}$ \\
\hline Sheep & $\begin{array}{c}122.15 \pm \\
5.36\end{array}$ & Saber, 1988 \\
\hline Goat & $95.85 \pm 8.12$ & Saber, 1988 \\
\hline $\begin{array}{l}\text { Kagani } \\
\text { goat }\end{array}$ & $113 \pm 0.84$ & Sarma, 2006 \\
\hline $\begin{array}{l}\text { Brown } \\
\text { bear }\end{array}$ & $343 \pm 13.86$ & $\underset{2013}{\text { Mihaylov }}$ et al., \\
\hline Lion & $\begin{array}{l}207.4 \pm \\
24.49\end{array}$ & $\begin{array}{l}\text { Saber and } \\
\text { Gummow, } \\
2015\end{array}$ \\
\hline Dog & $86.4 \pm 11.87$ & $\begin{array}{l}\text { Saber and } \\
\text { Gummow, } \\
2015\end{array}$ \\
\hline Cat & $20.8 \pm 1.95$ & $\begin{array}{l}\text { Saber and } \\
\text { Gummow, } \\
2015\end{array}$ \\
\hline $\begin{array}{l}\text { Indian } \\
\text { Blackbuck }\end{array}$ & $\begin{array}{c}107.83 \pm \\
0.86\end{array}$ & $\begin{array}{c}\text { Choudhary } \\
\text { and Singh, } \\
2015\end{array}$ \\
\hline
\end{tabular}

Table 3: Facial measurements of the Red fox's skull 
Sayed and Hamoda, 2021

\begin{tabular}{|c|c|c|c|c|}
\hline Parameters & Mean & SD & Min & Max \\
\hline Facial length $(\mathrm{cm})$ & 7.84 & 1.19 & 6.63 & 9.12 \\
\hline Facial width $(\mathrm{cm})$ & 4.89 & 0.44 & 4.43 & 5.30 \\
\hline $\begin{array}{c}\text { Least facial width } \\
(\mathrm{cm})\end{array}$ & 3.85 & 0.37 & 3.46 & 4.20 \\
\hline $\begin{array}{c}\text { Distance from } \\
\text { infraorbital } \\
\text { foramen to cranial } \\
\text { margins of the } \\
\text { orbit }(\mathrm{cm})\end{array}$ & 1.60 & 0.35 & 1.33 & 1.98 \\
\hline $\begin{array}{c}\text { Distance from } \\
\text { infraorbital } \\
\text { foramen to maxilla } \\
\text { alveolar process } \\
\text { (cm) }\end{array}$ & 0.90 & 0.22 & 0.71 & 1.14 \\
\hline
\end{tabular}

The average orbital length and width of the Red fox's skull were $2.67 \pm$ $0.03 \mathrm{~cm}$ and $2.55 \pm 0.06 \mathrm{~cm}$, respectively. The inter-orbital distance was $3.74 \pm 0.42$ $\mathrm{cm}$ at the rostral level, $3.64 \pm 1.2 \mathrm{~cm}$ at the middle level, and $4.52 \pm 1.14 \mathrm{~cm}$ at the caudal level. The mean value of the orbital capacity in the Red fox's skull was $9.34 \pm$ 0.17 cc (Table 4). The mean values of the greatest nasal bones length and width in the Red fox's skull were $5.87 \pm 0.73 \mathrm{~cm}$ and $1.40 \pm 0.15 \mathrm{~cm}$, respectively. The mean values of the palatine length and width in the Red fox's skull were $8.43 \pm$ $0.73 \mathrm{~cm}$ and $5.10 \pm 0.76 \mathrm{~cm}$, respectively (Table 4).

Table 4: Orbital, nasal and palatine measurements of the Red fox's skull

\begin{tabular}{|c|c|c|c|c|}
\hline Parameters & Mean & SD & Min & Max \\
\hline Orbital length (cm) & 2.67 & 0.03 & 2.64 & 2.71 \\
\hline Orbital width (cm) & 2.55 & 0.06 & 2.48 & 2.60 \\
\hline $\begin{array}{c}\text { Rostral inter-orbital } \\
\text { distance }(\mathbf{c m})\end{array}$ & 3.74 & 0.42 & 3.38 & 4.22 \\
\hline $\begin{array}{l}\text { Middle inter-orbital } \\
\text { distance }(\mathbf{c m})\end{array}$ & 3.64 & 1.2 & 2.73 & 5.10 \\
\hline $\begin{array}{l}\text { Caudal inter-orbital } \\
\text { distance }(\mathrm{cm})\end{array}$ & 4.52 & 1.14 & 3.61 & 5.80 \\
\hline Orbital capacity (cc) & 9.34 & 0.17 & 9.20 & 9.53 \\
\hline $\begin{array}{l}\text { Greatest nasal bone } \\
\text { length }(\mathrm{cm})\end{array}$ & 5.87 & 0.73 & 5.15 & 6.62 \\
\hline $\begin{array}{l}\text { Greatest nasal bones } \\
\text { width }(\mathrm{cm})\end{array}$ & 1.40 & 0.15 & 1.25 & 1.54 \\
\hline Palatine length $(\mathrm{cm})$ & 8.43 & 0.73 & 7.66 & 9.13 \\
\hline Palatine width $(\mathrm{cm})$ & 5.10 & 0.76 & 4.28 & 5.80 \\
\hline
\end{tabular}

SVU-IJVS, 4 (1): 66-78

Morphometric analyses of various indices in the Red fox's skull are shown in Table 5.

Table 5: Measured indices of the skull of the Red

\begin{tabular}{|c|c|c|c|c|}
\hline $\begin{array}{l}\text { ox's } \\
\text { Parameters }\end{array}$ & & & & $\frac{\text { skul }}{\text { Max }}$ \\
\hline $\begin{array}{l}\text { Skull / } \\
\text { Cephalic } \\
\text { index }\end{array}$ & 49.27 & 3.42 & 45.36 & 50.73 \\
\hline $\begin{array}{l}\text { Cranial } \\
\text { index }\end{array}$ & 49.87 & 3.96 & 46.60 & 54.27 \\
\hline Basal index & 30.97 & 2.33 & 28.8 & 33.43 \\
\hline $\begin{array}{l}\text { Foramen } \\
\text { magnum } \\
\text { index }\end{array}$ & 71.52 & 3.86 & 67.36 & 75.10 \\
\hline $\begin{array}{l}\text { Facial } \\
\text { index }\end{array}$ & 62.70 & 4.01 & 58.81 & 66.82 \\
\hline $\begin{array}{l}\text { Orbital } \\
\text { index }\end{array}$ & 97.87 & 5.22 & 93.94 & 103.80 \\
\hline $\begin{array}{l}\text { Nasal } \\
\text { index }\end{array}$ & 23.94 & 0.53 & 23.33 & 24.27 \\
\hline
\end{tabular}

The skull or cephalic, cranial and basal indices of the Red fox's skull were $49.27 \pm 3.42,49.87 \pm 3.96$ and $30.97 \pm$ 2.33, respectively; meanwhile the facial and orbital indices were $62.70 \pm 4.01$ and $97.87 \pm 5.22$, respectively. The foramen magnum and nasal indices of the Red fox's skull were $71.52 \pm 3.86$ and $23.94 \pm 0.53$, respectively. Measured skull, cranial, facial and orbital indices of different animal species are illustrated in Table 6 .

\section{DISCUSSION}

The phenotypic appearance of the head of various animals' species depends strongly on the skull's shape (Kunzel et al., 2003). Because of its significance, using the skull for determining taxonomic affiliations has been widely recommended due to its susceptibility to phenotypic changes (Brüenner et al., 2002).

Several previous studies have been performed on canine skull, and many morphometric data pertinent to the skull shape have been reported (Hidaka et al., 1998, Onar, 1999; Onar et al., 1997, 2001). The overall length of the wild and captive lion's skull were $31.27 \mathrm{~cm}$ and $30.35 \mathrm{~cm}$, respectively, while their overall skull width 
were $20.46 \mathrm{~cm}$ and $20.52 \mathrm{~cm}$, respectively (Zuccarelli, 2004). Recent study has been performed on skulls of three carnivores; lion, dog and cat and recorded that the skull lengths were $39.75 \pm 1.04 \mathrm{~cm}, 20.02$ $\pm 1.36 \mathrm{~cm}$ and $8.4 \pm 1.5 \mathrm{~cm}$, respectively, meanwhile, the skull widths were $28 \pm$ $2.16 \mathrm{~cm}, 10.04 \pm 0.56 \mathrm{~cm}$ and $6.8 \pm 1.4 \mathrm{~cm}$ respectively (Saber and Gummow, 2015). The average total length and width of skull in the Red fox as reported here were 17.64 $\pm 2.68 \mathrm{~cm}$ and $8.73 \pm 1.76 \mathrm{~cm}$, respectively, where the total skull length was about two-fold of its width. This finding was similar to previous measurements of the dog (Saber and Gummow, 2015).

The cranial length of the Red fox's skull was about two-fold of its width.

Table 6: Measured skull, cranial, facial and orbital indices of some animal species
Comparing with other canine, the cranial length and width were $18.86 \pm 4.77 \mathrm{~cm}$ and $11.85 \pm 1.98 \mathrm{~cm}$, respectively in lion, 5.96 $\pm 0.63 \mathrm{~cm}$ and $5.13 \pm 0.34 \mathrm{~cm}$, respectively in $\mathrm{dog}$, and $3.4 \pm 0.4 \mathrm{~cm}$ and $4.1 \pm 0.2 \mathrm{~cm}$, respectively in cat (Saber and Gummow, 2015). The foramen magnum width in the Red fox's skull was higher than its height. Skull capacity has been proposed to be not dependent on the skull form (Hajnis, 1962). Previous study performed on studied 7 species from the Felidae family and reported that the tiger had the greatest cranial cavity volume and length (Mihaylov and Dimitrov, 2010).

Recent study on canine skull clarified that the facial length and width are $17.88 \pm 5.59 \mathrm{~cm}$ and $17.75 \pm 5.19 \mathrm{~cm}$, respectively in lion, $14.16 \pm 0.89 \mathrm{~cm}$ and $5.37 \pm 0.35 \mathrm{~cm}$, respectively in $\mathrm{dog}$, and $5.0 \pm 1.5 \mathrm{~cm}$ and $5.9 \pm 1.2 \mathrm{~cm}$, respectively in cat (Saber and Gummow, 2015). The results of this study indicated that the

\begin{tabular}{|c|c|c|c|c|c|}
\hline Animal & $\begin{array}{c}\text { Skull } \\
\text { /Cephalic } \\
\text { index }\end{array}$ & $\begin{array}{l}\text { Cranial } \\
\text { index }\end{array}$ & $\begin{array}{l}\text { Facial } \\
\text { Index }\end{array}$ & $\begin{array}{l}\text { Orbital } \\
\text { index }\end{array}$ & Reference \\
\hline $\begin{array}{l}\text { German } \\
\text { Shepherd } \\
\text { Dog }\end{array}$ & 58.43 & 73.24 & $116.37 \pm 1.24$ & - & Onar, 1999 \\
\hline $\begin{array}{l}\text { Kagani } \\
\text { goat }\end{array}$ & $41.95 \pm 0.97$ & $58.55 \pm 1.54$ & $138.48 \pm 0.57$ & $\begin{array}{c}89.12 \pm \\
2.49\end{array}$ & Sarma, 2006 \\
\hline $\begin{array}{l}\text { Mehraban } \\
\text { Sheep }\end{array}$ & $53.57 \pm 3.26$ & $52.76 \pm 1.13$ & $85.44 \pm 1.89$ & $\begin{array}{l}21.46 \pm \\
0.68\end{array}$ & $\underset{2011}{\text { Karimi }}$ et $a l .$, \\
\hline $\begin{array}{l}\text { One- } \\
\text { humped } \\
\text { Camel }\end{array}$ & $40.99 \pm 0.33$ & $41.41 \pm 0.43$ & $96.35 \pm 0.95$ & - & $\begin{array}{c}\text { Yahaya et al., } \\
2012\end{array}$ \\
\hline $\begin{array}{l}\text { Tibetan } \\
\text { Gazelle }\end{array}$ & $43.22 \pm 0.44$ & $58.37 \pm 0.80$ & $116.37 \pm 1.24$ & - & Zhu, 2012 \\
\hline $\begin{array}{l}\text { Golden } \\
\text { Jackel }\end{array}$ & - & 71.28 & - & - & Monfared, 2013 \\
\hline $\begin{array}{l}\text { Markhoz } \\
\text { Goat }\end{array}$ & $47.77 \pm 1.96$ & $54.04 \pm 2.29$ & $100.77 \pm 6.85$ & - & $\begin{array}{l}\text { Goodarzi and } \\
\text { Hoseini, 2014 }\end{array}$ \\
\hline Lion & $71.28 \pm 2.71$ & $64.07 \pm 8.27$ & $113.9 \pm 58.57$ & $\begin{array}{l}72.55 \pm \\
3.04\end{array}$ & $\begin{array}{c}\text { Saber and } \\
\text { Gummow, 2015 }\end{array}$ \\
\hline Dog & $24.86 \pm 2.85$ & $\begin{array}{l}90.96 \pm \\
10.04\end{array}$ & $37.99 \pm 3.06$ & $\begin{array}{c}89.67 \pm \\
9.88\end{array}$ & $\begin{array}{c}\text { Saber and } \\
\text { Gummow, 2015 }\end{array}$ \\
\hline Cat & $80.79 \pm 6.08$ & $\begin{array}{c}121.24 \pm \\
18.3\end{array}$ & $\begin{array}{c}121.67 \pm \\
19.51\end{array}$ & $\begin{array}{c}83.48 \pm \\
10.6\end{array}$ & $\begin{array}{c}\text { Saber and } \\
\text { Gummow, 2015 }\end{array}$ \\
\hline $\begin{array}{l}\text { Common } \\
\text { Opossum }\end{array}$ & $50.0 \pm 2.93$ & - & $87.57 \pm 10.23$ & $\begin{array}{c}87.37 \pm \\
3.60\end{array}$ & Mohamed, 2018 \\
\hline $\begin{array}{l}\text { Indian } \\
\text { Blackbuck }\end{array}$ & $46.12 \pm 0.12$ & $\begin{array}{c}59.00 \pm 0 \\
.11\end{array}$ & $80.67 \pm 0.44$ & $\begin{array}{c}107.33 \pm \\
0.4\end{array}$ & $\begin{array}{l}\text { Choudhary and } \\
\text { Singh, } 2015\end{array}$ \\
\hline $\begin{array}{c}\text { Bardhoka } \\
\text { sheep }\end{array}$ & $41.53 \pm 2.38$ & $48.99 \pm 1.74$ & $80.70 \pm 3.45$ & $\begin{array}{c}93.06 \pm \\
4.81\end{array}$ & $\underset{2020}{\operatorname{Giindemir}} \operatorname{et} a l .$, \\
\hline
\end{tabular}


cranial length of the Red fox's skull was higher than the facial length, a finding similar to that found in lion (Saber and Gummow, 2015) and Common Opossum (Mohamed, 2018). However, the facial length of the skull was detected higher than the cranial length in dog and cat (Saber and Gummow, 2015).

Morphological and morphometrical analysis of the infraorbital foramen is very important for locating the foramen; a step of a great significance is in infraorbital nerve block (Rahman et al., 2013). Moreover, infraorbital foramen identification is essential for the prohibition of iatrogenic injury of the infraorbital nerve during maxillofacial surgeries (Kazkayasi et al., 2001; Raschke et al., 2013; Kotrashetti et al., 2015). For decades, the relative cross sectional area of the infraorbital foramen has been used in ecological and phylogenetic interpretations of the fossil record (Shigehara et al., 2002; $\mathrm{Ni}$ et al., 2004; MacPhee and Horovitz, 2004, Rossie et al., 2006). Previous studies have localized the level of the infraorbital foramen through determining its distance from nearby bony landmarks, and also soft tissue structures such as alveolar border of the maxilla, medial and lateral palpebral commissures, zygomatico-maxillary and fronto-maxillary sutures, as well as supraorbital foramen (Gupta, 2008; Liu et al., 2011; Zheng et al., 2012; Ercikti et al., 2017).

The orbital length and width of the lion were $7.75 \pm 0.50 \mathrm{~cm}$ and $5.63 \pm 0.48$ $\mathrm{cm}$, respectively, and those of the dog were $3.3 \pm 0.28 \mathrm{~cm}$ and $2.8 \pm 0.18 \mathrm{~cm}$, respectively, while in the cat were $2.8 \pm$ $0.65 \mathrm{~cm}$ and $2.3 \pm 0.27 \mathrm{~cm}$, respectively (Saber and Gummow, 2015), confirming findings of this study, where the orbital length was higher than the orbital width. Archana et al. (2006) studied the orbital cavity of the Himalayan leopard's skull and reported that the orbital cavity dimension was about $6 \times 5 \mathrm{~cm}$. The rostral, middle and caudal inter-orbital distances were $13.55 \pm 3.03 \mathrm{~cm}, 8.4 \pm 0.71$ $\mathrm{cm}$, and $15.25 \pm 3.86 \mathrm{~cm}$, respectively in the lion, $4.35 \pm 0.51 \mathrm{~cm}, 3.59 \pm 0.87 \mathrm{~cm}$, and $5.11 \pm 0.66 \mathrm{~cm}$, respectively in the $\mathrm{dog}$, in addition to $2.4 \pm 4.14 \mathrm{~cm}, 1.6 \pm$ $0.23 \mathrm{~cm}$, and $2.8 \pm 0.18 \mathrm{~cm}$, respectively in the cat (Saber and Gummow, 2015), assuring results of this study, where the inter-orbital distance being wider caudally and narrower in the middle.

The mean value of the orbital capacity in the Red fox's skull was $9.34 \pm$ 0.17 cc. Orbital analysis of different carnivores revealed that measured orbital capacities of lion, dog, and cat were $80.5 \pm$ $21,44 \mathrm{cc}, 10.9 \pm 3.21 \mathrm{cc}$, and $3.8 \pm 1.6 \mathrm{cc}$, respectively (Saber and Gummow, 2015). The nasal length of the Red fox's skull was about 4 fold of its width.

Among measured indices in the skull of the Red fox, the orbital index was the greatest, while cranial index was the greatest in the dog and cat skull (Saber and Gummow, 2015), and the facial is the greatest in the skull of lion (Saber and Gummow, 2015). The high cranial index in the dog was proposed as an indicator for a wider braincase related to its length (Schmidt et al., 2011). Skull index was previously used for differentiating animal's skulls, where skull indices of $57.13 \pm 3.64$ and $54.25 \pm 4.29$ were recorded for differentiating the mesocephalic and the dolichocephalic skulls of Byzantine dogs (Onar et al., 2012). In the cat, the round skull type was characterized by an increased braincase height (Künzel et al., 2003). The cranial indices of the skulls of the Iranian mixed-breed dogs, Golden jackal, and Persian cat were 66.37, 71.28, and 55.55, respectively (Monfared, 2013 a, b, c). Previous study estimated the cranial index and cranial capacity of various species including the gray fox, pig, bull, raccoon, deer, badger, marmot, Prairie dog, 
cat, jack rabbit and human, and according to findings, it was assumed that predators have a higher intelligence, compared to prey (Hieck and Dougherty, 2013).

\section{CONCLUSION}

The morphometric analysis of the skull of the Red fox plays a critical role in the identification of this species. Moreover, craniofacial studies will facilitate determination of skull deformations and differentiation of different animal skulls of certain regions. Osteometric analyses of the Red fox's skull will provide baseline anatomy information on the skull morphometry, which is necessary for comparative anatomy, developmental studies and also for clinical veterinary practice. The findings reported here will motivate and assist other clinical studies conducting on the Red fox such as application of surgical operations on the head region.

\section{ACKNOWLEDGEMENTS}

The authors thank technicians of Anatomy and Embryology Department, Faculty of Veterinary Medicine, Sohag University, Egypt for their support with processing of animas' skulls for skeleton preparation. The current study hasn't any funds from any organizations or institutions.

\section{CONFLICT OF INTEREST}

The authors declare that they do not have any conflict of interest.

\section{REFERENCES}

Aničić M, Vučićević I, Vasković N, Radojičić S, Juntes P, Nešić S, Aleksić-Kovačević S, Marinković D (2018). Histopathological characteristics and expression of
CDV-NP antigen in the brain of serologically positive spontaneously infected red foxes (Vulpes vulpes) in Western Serbia. Acta Veterinaria, 68(4): 434-444.

Archana D, Scharma N, Rajput R, Kishtwaria RS, Bhardwaj RL, Sidhakar LS (2006). Anatomy of north-western Himalayan leopard. The Indian Journal of Animal Sciences, 76(8): 616-617.

Basuony M, Saleh M, Riad A, Fathy W (2005). Food composition and feeding ecology of the Red Fox Vulpes vulpes (Linnaeus, 1758) in Egypt. Egyptian Journal of Biology, 7: 96-102.

Cavallini, P., Santini, S., 1995. Age determination in the Red fox in a Mediterranean habitat. Zeitschrift für Säugetierkunde, 60: 136-142.

Choudhary OP, Singh I (2015). Morphometrical studies on the skull of Indian Blackbuck (Antelope cervicapra). International Journal of Morphology, 33(3): 868-876.

Constantinescu GM, Schaller O (2012). Illustrated veterinary anatomical nomenclature. 3rd Ed., Enke Verlag-Stuttgard, pp: 10-37.

Dalga S, Aslan K, Akbulut Y (2018). A morphometric study on the skull of the Hemshin sheep. Van Veterinary Journal, 29(3): 125-129.

Ercikti N, Apaydin N, Kirici Y (2017). Location of the infraorbital foramen with reference to soft 
tissue landmarks. Surgical and

Radiologic Anatomy, 39(1): 11-15.

Fedriani JM, Fuller TK, Sauvajot RM, York EC (2000). Competition and intraguild predation among three sympatric carnivores. Oecologia, 125: 258-270.

Goodarzi N, Hoseini TS (2014). Morphologic and osteometric analysis of the skull of Markhoz goat (Iranian Angora). Veterinary Medicine International, Vol. 2014, Article ID 972682.

Gündemir O, Duro S, Jashari T, Kahvecioğlu O, Demircioğlu I, Mehmeti H (2020). A study on morphology and morphometric parameters on skull of the Bardhoka autochthonous sheep breed in Kosovo. Anatomia Histologia Embryologia, 49(3): 365-371.

Gupta T (2008). Localization of important facial foramina encountered in maxillo-facial surgery. Clinical Anatomy, 21(7): 633-640.

Guskov VY (2014). Skull-based method of age determination for the Brown bear Ursus arctos Linnaeus, 1758. Achievements in the Life Sciences, 8(2): 137-141.

Hajnis K (1962). Evaluation of methods used in the calculation of cranial capacity according to lineal dimensions. Ceskoslovenská Morfologie, 10: 220-233.

Hidaka S, Matsumoto M, Hiji H, Ohsako S, Nishinakagawa H (1998). Morphology and morphometry of skulls of Raccoon dogs,

Nyctereutes procyonoides and Badgers, Meles meles. The Journal of Veterinary Medical Science, 60(2): 161-167.

Hieck K, Dougherty M (2013). Cranial volume / intelligence. Finding the intelligence of an animal. Field study presented to STEM Teacher Academy, Rider University. http://riderstem.weebly.com/cranial -volume-intelligence.html

Karimi I, Onar V, Pazvant G, Hadipour M, Mazaheri Y (2011). The cranial morphometric and morphologic characteristics of Mehraban sheep in Western Iran. Global Veterinaria, 6(2): 111-116.

Kazkayasi M, Ergin A, Ersoy M, Bengi O, Tekdemir I, Elhan A (2001). Certain anatomical relations and the precise morphometry of the infraorbital foramen--canal and groove: an anatomical and cephalometric study. Laryngoscope, 111(4): 609-614.

Knobel DL, Cleaveland S, Coleman PG (2005). Re-evaluating the burden of rabies in Africa and Asia. Bulletin of the World Health Organization, 83(5): 360-368.

König HE, Liebich HG (2013). Veterinary anatomy of domestic mammals: Textbook and colour atlas. 6th Ed., Stuttgard, Germany: Schattauer Verlag, pp: 54-89.

Kotrashetti SM, Kale TP, Bhandage S, Kumar A (2015). Infraorbital nerve transpositioning into orbital floor: a modified technique to minimize 
nerve injury following zygomaticomaxillary complex fractures. Journal of the Korean Association of Oral and Maxillofacial Surgeons, 41(2): 7477.

Künzel W, Breit S, Oppel M (2003). Morphometric investigations of breed-specific features in feline skulls and considerations on their functional implications. Anatomia Histologia Embryologia, 32(4): 218-23.

Liu DN, Guo JL, Luo Q, Tian Y, Xia CL, Li YQ, Su L (2011). Location of supraorbital foramen/notch and infraorbital foramen with reference to soft- and hard-tissue landmarks. The Journal of Craniofacial Surgery, 22(1): 293-296.

MacPhee R, Horovitz I (2004). New craniodental remains of the quaternary Jamaican monkey Xenothrix mcgregori (Xenotrichini, Callicebinae, Pitheciidae), with a reconsideration of the Aotus hypothesis. American Museum Novitates, 3434: 1-51.

Mazák JH (2008). Craniometric variation in the tiger (Panthera tigris): Implications for patterns of diversity, taxonomy and conservation. Mammalian Biology, 75(1): 45-68.

Mihaylov R, Dimitrov R (2010). Volume and sizes of the cranial cavity in some animals from Felidae family. Journal of Animal Science, 47(5): 67-75.
Mihaylov R, Dimitrov R, Raichev E,

Kostov D, Stamatova-Yiovcheva

$\mathrm{K}$, Zlatanova D, Bivolarski B

(2013). Morphometric features of the head skeleton in Brown bear (Ursus Arctos) in Bulgaria. Bulgarian Journal of Agricultural Science, 19(2): 331-337.

Mohamed R (2018). A Descriptive morphometric approach of the skull and mandible of the Common Opossum (Didelphis marsupialis Linnaeus, 1758) in the Caribbean and its clinical application during regional anaesthesia. Veterinary Sciences, 5(1): 29.

Monfared AL (2013a). Anatomical study of the skull of the adult dogs and its clinical value during regional anesthesia. Global Veterinaria, 10(4): 459-463.

Monfared AL (2013b). Macroanatomical investigation of the skull of Golden Jackal (Canis aureus) and its clinical application during regional anethesia. Global Veterinaria, 10(5): 547-550.

Monfared AL (2013c). Anatomy of the Persian cat's skull and its clinical value during regional anesthesia. Global Veterinaria, 10(5): 551-555.

Ni X, Wang Y, Hu Y, Li C (2004). An euprimate skull from the early Eocene of China. Nature, 427: 6568.

Nomina Anatomica Veterinaria (2017). 6 th ed. (revised). Prepared by the International Committee on Veterinary Gross Anatomical Nomenclature (I.C.V.G.A.N.). 
Authorized by the World

Association of Veterinary

Anatomists (W.A.V.A.), Knoxville.

TN (USA). Published by the

Editorial Committee Hanover

(Germany), Ghent (Belgium), Columbia, MO (U.S.A.), Rio de

Janeiro (Brazil).

Olopade J, Onwuka S (2008). A craniometric analysis of the skull of the Red Sokoto (Maradi) goat (Capra hircus). European Journal of Anatomy, 12(1): 57-62.

Onar V (1999). A morphometric study on the skull of German shepherd dog (Alsatian). Anatomia Histologia Embryologia, 28(4): 253-256.

Onar V, Çakirlar C, Janeczek M, Kiziltan Z (2012). Skull typology of Bezantine dogs from the Theodosius Harbour at Yenikapi, Istanbul. Anatomia Histologia Embryologia, 41(5): 341-352.

Onar V, Güneş K (2003). On the variability of skull shape in German shepherd (Alsatian) puppies. The Anatomical Record, 272A(1): 460-466.

Onar V, Mutus R, Kahvecioğlu KO (1997). Morphometric analysis of the foramen magnum in German Shepherd dogs (Alsatians). Annals of Anatomy, 179(6): 563-568.

Onar V, Özcan S, Pazvant G (2001). Skull typology of adult male kangal dogs. Anatomia Histologia Embryologia, 30(1): 41-48.

Osborn DJ, Helmy I (1980). The contemporary land mammals of
Egypt (including Sinai). Chicago,

USA: Field Museum of Natural

History.

Özcan S, Aksoy G, Kürtül I, Aslan K, Özüdogru Z (2010). A comparative morphometric study on the skull of the Tuj and Morkaraman sheep. Kafkas Universitesi Veteriner Fakultesi Dergisi, 16(1): 111-114.

Özkan E, Siddiq AB, Kahvecioğlu KO, Öztürk M, Onar V (2019). Morphometric analysis of the skulls of domestic cattle (Bos taurus L.) and water buffalo (Bubalus bubalis L.) in Turkey. Turkish Journal of Veterinary and Animal Sciences, 43(4): 532-539.

Rahman M, Richter EO, Osawa S, Rhoton Jr AL (2013). Anatomic study of the infraorbital foramen for radiofrequency neurotomy of the infraorbital nerve. Neurosurgery, 64(5): 423-427.

Rao GS (1967). Cranial capacity of adult bovine skull. Journal of the Anatomical Society of India, 16: 121-127.

Raschke R, Hazani R, Yaremchuk MJ (2013). Identifying a safe zone for midface augmentation using anatomic landmarks for the infraorbital foramen. Aesthetic Surgery Journal, 33(1): 13-18.

Rogers TL (2005). Determining the sex of human remains through cranial morphology. Journal of Forensic Sciences, 50(3): 493-500.

Rossie J, Ni X, Beard K (2006). Cranial remains of an Eocene tarsier. 
Proceedings of the National Academy of Sciences of the United States of America, 103(12): 43814385 .

Saber AS (1989). Cranial capacity of sheep and goat. Assiut Veterinary Journal, 21: 1-6.

Saber AS, Gummow B (2015). Skull morphometry of the lion (Panthera leo), dog (Canis lupus familiaris) and cat (Felis catus). Journal of Veterinary Anatomy, 8(1): 13-30.

Saleh MA (1993). Habitat diversity and land vertebrates. In: Habitat diversity: Egypt, M. Kassas, (Ed.). Publications of National Biodiversity Unit. No. 1, Cairo, pp: 131-165.

Sarma K (2006). Morphological and craniometrical studies on the skull of Kagani goat (Capra hircus) of Jammu region. International Journal of Morphology, 24(3): 449455.

Schmidt MJ, Neumann AC, Amort KH, Failing K, Kramer M (2011). Cephalometric measurements and determination of general skull type of Cavalier King Charles Spaniels. Veterinary Radiology and Ultrasound, 52(4): 436-440.

Seimenis A (2008). The rabies situation in the Middle East. Developments in Biologicals, 131: 43-53.

Shigehara N, Takai M, Kay R, Ko Aung A, Soe A, Tun S, Tsubanato T, Thein $\mathrm{T}$ (2002). The upper dentition and face of Pondaungia cotteri from central Myanmar. Journal of

Human Evolution, 43(2): 143-166.

Simoens R, Poles R, lauwers H (1994). Morphometric analysis of foramen magnum in Pekingese dogs. American Journal of Veterinary Research, 55(1): 33-39.

Statham MJ, Murdoch J, Janecka J, Aubry KB, Edwards CJ, Soulsbury CD, Berry O, Wang Z, Harrison D, Pearch M, Tomsett L, Chupasko J, Sacks BN (2014). Range-wide multilocus phylogeography of the red fox reveals ancient continental divergence, minimal genomic exchange and distinct demographic histories. Molecular Ecology, 23(19): 4813-4830.

Stuart C, Stuart T (2017). Mammals of North Africa and the Middle East. London, New Delhi, New York, Sydney: Bloomsbury Publishing.

Stubbe M (1980). The red fox-Vulpes vulpes (L., 1758) in Europe. In: The red fox: Symposium on behaviour and ecology, E. Zimen, (Ed.). Dordrecht, Netherlands: Springer, pp: 27-34.

Virgós E, Travaini A (2005). Relationship between small-game hunting and carnivore diversity in central Spain. Biodiversity \& Conservation, 14: 3475.

Wehausen JD, Ramey RR (2000). Cranial morphometric and evolutionary relationships in the northern range of Ovis canadensis. Journal of Mammalogy, 81(1): 145-161. 
Yahaya A, Olopade JO, Kwari D, Wiam

IM (2012). Osteometery of the

skull of one-humped camels. Part I:

Immature animals. Italian Journal

of Anatomy and Embryology, 117(1): 23-33.

Zheng WX, Guo JL, Song BX, Liu XL, Lv DL, Tian Y, Li YQ, Cheng FB (2012). Location of the supraorbital and infraorbital foramen with references to the soft tissue landmarks in a Chinese population. The Journal of Craniofacial Surgery, 23(4): 1154-1155.

Zuccarelli MD (2004). Comparative morphometric analysis of captive vs. wild African lion (Panthera leo) skulls. The journal of the Beta Biological Society, 75(4): 131-138. 